\title{
PSYCHO-SOCIOLOGICAL PERSONALITY TRAITS OF SEXUAL OFFENDERS
}

\author{
SlobodankaTodoroska-Gjurchevska ${ }^{1, a}$ \\ Lidija Naumovska ${ }^{b}$ \\ Atanas Kozarev
}

Faculty of detectives and criminology, European University-Skopje ${ }^{a}$

Faculty of Economics, European University-Skopje ${ }^{b}$

Faculty od Law, European University-Skopje

\author{
Original scientific papers
}

Received: 20.02 .2015

UDC: $343.54: 159.9$

Accepted: 16.03.2015

\begin{abstract}
Criminality is an extremely heterogeneous social phenomenon that includes various kinds of deviant behavior. It also includes sexual criminality (crimes against sexual freedom and moral), which has highly negative impact on society and endangers the most intimate parts of a person's life. The aim of this survey is to outline a structure of psychological features of sexual offenders, to determine the degree of their development and the way in which they are connected, as well as to describe certain social and sociological phenomena that are typical of sexual offenders. The results that have been achieved during this survey will successfully be implemented into the practical work of penal institutions in the Republic of Macedonia in order to ensure successful resocialisation and reintegration of sexual offenders in the society. Our experience and knowledge are compatible with world-wide trends saying that sexual offenders are mentally healthy people and that they cannot be included in any diagnostic category. The main results of this survey can be summed up into several points: in general, sexual offenders are male, aged between 26 and 33, with minimal education and without profession or employment. Usually, they do not behave in pathological manner and they are mentally healthy people. It is believed that resocialisation as well as a complex treatment will be necessary for people convicted of sexual offences: not only will it represent prevention from committing new crimes, it will also be a breeding ground for their active participation in life out of the penal institutions.

Key words: Sexual criminality, sexual offence, homicide, personality, personality features/traits, urges, resocialization, treatment, prostitution, pornography.

\section{INTRODUCTION}

In contemporary conditions of life in different countries of the world criminal legal issue which treats and regulates behaving that threatens the freedom of an individual when doing sexual relationship is not regulated in the same way. A wide variety of sexual criminal attacks (of which the most serious is rape) is mainly classified as a separate group of criminal acts, which essentially are the most numerous, and at the same time attack the dignity of man. Some other torts, especially those connected with prostitution, organized crime and sexual abuse of children in most countries of the world re-

ceive much more attention not only from scientific and professional circles but from the general public as well. Although sexual criminality constitutes an insignificant part of the total crime rate, (which is typical of other countries worldwide), this type of criminality is an actual issue because: it is a very serious form of a crime with typical violent elements which are directed against human freedom of sexual behaving and because of this, all clasified forms of rape (as well as others more serious forms of sexual offences) disturb the public and cause fear, anxiety and revolt.
\end{abstract}

\footnotetext{
${ }^{1}$ Correspodence to:

SlobodankaTodoroska-Gjurchevska $\mathrm{PhD}$, Faculty of detectives and criminology,

European University-Skopje, Republic of Macedonia

Tel: ++389 23202126

E-mail: slobodanka.todoroska@eurm.edu.mk
} 
The review of the research that concerns the psychosocial characteristics of perpetrators of sex crimes indicates that sex offenders are not aggressive, hostile or impulsive and that they can't be diagnosed with being sexual psychopaths. Sex offenders are emotionally deranged personalities who can't fit their sexual practice in legal frames. Considering some researches in which some of the characteristic features of the sex offenders are given, it will be useful to determine the personality traits and social characteristics typical of perpetrators of sex crimes, the level at which they are developed and what their mutual connection and structure is. More specifically, it will be the coefficient of intelligence (IQ), the primary feature of an individual distrustful, the dimension of the psychoticism, then the psychological type of the individual (introversion-extraversion), the dimensions of emotional stability-neuroticism, then psychoticism as a dimension, education, the success during school, profession, premarital sexual experience and recidivism. The goal of this research was to determine the psychological structure of sex offenders and to show their social characteristics.

The target of this research is to give answer to the following questions:

1.To determine if there is a difference regarding the intellectual abilities between perpetrators of sexual offenses and perpetrators of blood tort,

2.To determine if there is a difference regarding the distrustful (feature of an individual) between perpetrators of sexual offenses and perpetrators of blood tort,

3.To determine if there is a difference regarding the dimension of psychoticism between perpetrators of sexual offenses and perpetrators of blood tort,

4.To determine if there is a difference regarding the psychological type (introversion - extraversion) between perpetrators of sexual offenses and perpetrators of blood tort,

5.To determine if there is a difference regarding the dimension of the neuroticism-stability between perpetrators of sexual offenses and perpetrators of blood tort,

6. To determine if there is a difference regarding the education between perpetrators of sexual offenses and perpetrators of blood tort,

7.To determine if there is a difference regarding the success during school between perpetrators of sexual offenses and perpetrators of blood tort,
8. To determine if there is a difference regarding the profession between perpetrators of sexual offenses and perpetrators of blood tort,

9. To determine if there is a difference regarding the premarital sexual experience between perpetrators of sexual offenses and perpetrators of blood tort,

10.To determine if there is a difference regarding the recidivism between perpetrators of sexual offenses and perpetrators of blood tort,

\section{METHODS}

In this research, a method of sample of perpetrators of sexual offenses and perpetrators of blood tort is applied. Perpetrators of sexual offenses make an experimental group while perpetrators of blood tort make a control group. The experimental group consists of 64 respondents who have committed a sexual offense while the control group consists of 63 respondents who have committed blood tort. The total number of the two groups is 127 respondents who have been serving prison sentence in CPA - Idrizovo near Skopje.

The experimental group consisted of male respondents aged between 18 and 66. 39 respondents from this group were convicted of a criminal offense "Raping" under the article 186 of the CC of RM. In addition to the criminal offense "Raping " 2 of the respondents were also convicted of criminal offense "Incest" under the article 194 of the CC of RM. In addition to the criminal offence raping one of the respondents was also convicted of the criminal offense "Kidnapping" under the article 141 of the CC of RM; besides the criminal offense raping 2 of the respondents were also convicted of criminal offense "murder" under the article 123 of the CC of RM. Ten respondents were convicted of criminal offense "Sexual assault of a child" under the article 188 of the CC of $\mathrm{RM}$, three respondents were convicted of criminal offense "Against natural fornication" under the article 185 from the CC of RM, two respondents of criminal offense "Indecent assault " under the article 184 of the CC of RM, six respondents of criminal offense "Statutory rape of a helpless person" under the article 187 of the CC of RM and four of the respondents were convicted of criminal offense "Incest" under the article 194 from the CC of RM. For these criminal offenses sentences of imprisonment in duration of 1-10 years were pronounced. 
The control group consisted of 63 respondents who committed blood tort. 53 respondents were convicted of criminal offense "murder" under the article 123 of the CC of RM, 7 respondents were convicted of criminal offense "attempted murder" under the article 123 att. 19 from the CC of RM and 3 respondents were convicted of criminal offense "manslaughter" under the article 125 from the CC of RM. For these criminal offenses sentences for imprisonment in duration of 3 years to life imprisonment were pronounced. This group consisted of respondents aged between 18 and 60.Participation in the questioning was voluntary, and one of the basic conditions was good command of Macedonian language.

Data collection lasted from June 1999 to June 2001. All the respondents were questioned individually. Raven's progressive matrices were used to test the intellectual abilities (nonverbal test for measuring intelligence). Literacy and education were irrelevant factors for the application of this test.

Two questionnaires were used to examine personal features: PIE-Pluch personality test (profile index emotion) and EPIQ (Ajzec personal inventor of personality). Both questionnaires were given separately. A questionnaire for data collection was used as well. Statistical procedures such as x2 (xi-square), $\mathrm{t}$ (te-test),factor analysis and percentages were used for the procession of the data obtained.

\section{RESULTS AND DISCUSSION}

\section{The influence of intellectual abilities on sen- tenced for sexual and blood crimes}

It is supposed in our research about the influence of intellectual abilities on the attitude of the samples that both of them, that either sexual or blood delicts differ statistically. 35 samples or $27,5 \%$ out of whole belong to the category of defect intelligence (IQ up to 70 ). 18 of the tested or $51,4 \%$ committed sexual crime. This result implies that it is likely that there is an equal possibility of investigated cases to commit crime of this type. 22 of the studied or $17,3 \%$ out of the whole sample belong to the category of people with low coefficient intelligence (IQ 17- 79); 15 tested or $68,2 \%$ committed sexual crime and 7 or $31,8 \%$ committed blood delict. This result implies that there is a greater possibility that these people commit sexual crime; 26 tested or $20,4 \%$ of the whole sample belong to the category of people with intelligence under average (IQ 80-89); 14 tested or $53,8 \%$ committed sexual crime and 12 or $46,2 \%$ committed blood delicts. These results witness that there is an equal possibility of this category to commit sexual or blood delict, 37 or $29,1 \%$ of the whole sample belong to the category of people with average intelligence (IQ 90-109). 13 tested have committed and 24 0r $64,9 \%$ blood delicts. The former implies that there is a rather high possibility of the category of people with average intelligence to commit a sexual delict. 6 tested or $4,7 \%$ of the whole sample belong to the category of intelligence above average (IQ 110-119). Three tested or 50,0\% committed sexual crime and the same number applies to those with blood delicts. This number is not imposing so that the comment is out of question.

One of the tested or $0,78 \%$ from the whole sample belong to the category of people with high intelligence (IQ 120-128) and he committed sexual crime. This, again, is not an imposing number so the comment is out of question again. Based on the former study results, it is easy to conclude that intellectual abilities are an irrelevant factor when it comes to committing sexual or blood delicts.

\section{The influence of the relation character of crimi- nals - blood criminals}

In our research about the influence of the relation character-blood delicts it is assumed that both of the samples, that either sexual or blood delicts differ statistically. 71 tested or 55,9\% out of whole sample belong to the category in which the result is low. 29 tested or $40,8 \%$ committed sexual delicts and 42 or $59,2 \%$ committed blood delict. These results show the fact that the opposing character of the criminal results in low score of existing possibility of committing blood delicts. 33 tested or $25,3 \%$ out of whole samples belong to the category of low score (41-60). 23 tested or $67,7 \%$ committed a sexual delict and 10 tested 03 30,3\% committed a blood delict. These results suggest that tested people with low score are more likely to commit sexual delict.

23 or $18,1 \%$ of the people tested are in the category of high score (more than 61) of opposing character. 12 tested or $52,2 \%$ committed a sexual delict and 11 tested or $47,8 \%$ committed a blood delict. These results witness that those with high score of opposing character have an equal possibility of committing a sexual or a blood crime. 
Based on the previously mentioned data it is easy to conclude that the opposing character is a relevant indicator for committing sexual crimes. Criminals that commit sexual crimes show stubbornness in their character. Also, they are prone to non-acceptance and opposing. These characteristics can convey a correlation with their opposing to law and committing sexual crimes. People tested with low scores (people with lack of self-confidence, non-initiating) have a higher tendency of committing sexual crimes. Those who have a high score in this field (stubborn, evil and prone to opposing) show equal tendency to commit sexual or blood crimes.

\section{Influence of psychoticism in the behavior of criminals who committed sexual or blood crimes}

In our research about the influence of psychoticism in the behavior of criminal that both of them, it is supposed that either sexual or blood delicts criminals differ statistically. 124 tested or $97,6 \%$ of the whole sample belong to the category in which the criminals have low score (up to 12). 61 tested or $49,2 \%$ committed a sexual crime and 63 or $49,2 \%$ committed blood delicts. This data show equal tendency to commit sexual or blood crimes; 3 of the examined or $2,36 \%$ out of the whole sample belong to the category where the examined showed a middle intensity score (13-15). All of them committed sexual crimes. On the basis of the previous data, the criminals of sexual crime manifest middle score of psychoticism (rigidness, emotional numbness, diffilcuties in emotional and interpersonal relations, difficulties in memory, non-differential social attitudes). None of the whole sample belongs to the category of explicit psychoticsm. All of those showing psychoticism committed a sexual crime, while those who have a low score have the same tendency to commit crime of these two types.

Psychoticism is a relevant indicator of sexual and blood crimes.

\section{Influence on psychological type of personality (extraversion v.s. introversion) on the behavior of sexual and blood criminals}

In our research about the influence on the psychological type of personality on the behavior the samples, it is supposed that either sexual or blood criminals differ statistically. 14 tested or $11,0 \%$ out of the whole sample belong to the category of introvert criminals (up to 7). 9 examined or $4,3 \%$ committed a sexual crime and 5 or $35,7 \%$ committed a blood delict. These parameters show that introvert people are more likely to commit sexual crimes; 28 tested or $22,0 \%$ out of the whole sample belong to the category of people with both extrovert and introvert characteristics (from 8-10 score). 16 tested or $57,1 \%$ committed a sexual delict, while 12 or $42,9 \%$ committed a blood crime. These results show that those who belong to the latter category are more prone to sexual crimes; 36 tested or $28,3 \%$ out of the whole sample have low results in introversion (11-13). 18 examined or $50,0 \%$ committed a sexual crime and the same number applies to blood delict. These results show that those who belong to this category manifest equal tendency for both sexual or blood crimes. 49 tested or $38,5 \%$ out of the whole sample belong to the category of extreme extroversion (more than 14). 21 of the examined or $42,9 \%$ committed a sexual crime and 28 or $57,1 \%$ committed a blood crime. This is an indication that the latter are more likely to commit blood delicts.

Based on the former evidence, we can conclude that introvert people (more prone to introspection, difficulties in communication and prone to isolation) are prone to sexual crimes. Examined people with characteristics of introversion and extroversion have equal tendency to commit sexual and blood crimes. Those with middle intensity of extroversion are also prone to those crimes. On the other hand, those with expressed extroversion have a higher tendency to commit sexual delict.

Psychological type of personality (extroversion, introversion) is a relevant factor in committing sexual crimes.

\section{Influence of dimension (neuroticism-introver- sion) of way of behaving of tested that have com- mitted crime}

In our research about the influence of dimension of the way of behaving of tested on the attitude of the samples of both types, it is supposed that either sexual or blood delicts differ statistically. 30 examined or $23,6 \%$ out of the whole sample belong to the category of low risk of neuroticism i.e emotional stability (up to 8). 17 examined or $56,7 \%$ committed a sexual crime and 13 examined or $43,3 \%$ committed a blood crime. These parameters show that examined people with low neuroticism have equal tendency to commit sexual and blood crimes; 26 examined or $20,4 \%$ out of whole sample belong to the category of people between emotional stability and neuroticism (9-11). 
14 examined 53,8\% committed a sexual crime and 12 or $42,9 \%$ committed a blood delict. This data indicate that examined who belong to this category manifest equal tendency to commit sexual or blood crimes; 23 examined or $18,1 \%$ out of the whole sample have middle level of expression of neuroticism (12-15). 11 examined or $47,8 \%$ committed a sexual crime and 12 or $52,2 \%$ committed a blood delict. This data shows that those who belong to this category have the same tendency to commit sexual or blood delicts; 48 of the examined or $37,7 \%$ out of the whole sample belong to the category of expressed neuroticism (up to 15). 22 tested or $45,8 \%$ committed a sexual crime, and 26 or $54,2 \%$ committed a blood crime. This data show that the examined who fall into this category manifest equal possibility to commit sexual or blood crime.

Based on the former data, the category of people with low neuroticism manifest equal possibility of committing sexual or blood delicts. Those who fall in the category of people between emotional stability and neuroticism have equal possibility for sexual and blood crimes. The examined people who have emotional instability and neuroticism with middle intensity have again, the same tendency. The same tendency is also noticed among those who have extreme manifestation of neuroticism.

\section{The impact of education on the conduct of re- spondents who have committed sexual or blood torts}

In our research about the influence of education on the attitude of the samples that both of them, it is supposed that either sexual or blood delicts differ statistically. 11 respondents or $8.66 \%$ of the total sample are illiterate. The interpretation of these statistical data will not be kept as a representation because the sample is small, under 20.75 respondents or $59.05 \%$ of the total sample who committed sexual or blood torts have completed primary education. 36 respondents or $48.0 \%$ committed a sexual tort and 39 or $52.0 \%$ committed a blood tort. These data suggest that respondents who have primary education manifest the same probability to do sexual or blood torts. 36 respondents or $28.34 \%$ of the total sample who committed sexual or blood torts, completed secondary education. 17 respondents or $47.2 \%$ committed a sexual offense and 19 respondents or $52.8 \%$ committed a blood tort. These data suggest that the respondents who have secondary education manifest the same probability to commit a sexual or blood tort. 4 respondents or $3.14 \%$ of the total sample who committed sexual or blood torts have college or university education. These data will not be commented because the representation in the sample is less than 20. Based on the data we can conclude that respondents who are illiterate or who have primary and secondary education manifest the same probability to commit sexual or blood tort.s Education is an irrelevant factor in the commission of sexual offenses.

\section{The impact of educational success on the con- duct of respondents having committed sexual or blood torts}

The assumption in our research regarding the impact of success achieved during school on the behavior of respondents who committed sexual or blood torts is that the two samples tested are significantly different when it comes to statistics. 6 respondents or $4.76 \%$ of the total sample who committed sexual or blood torts have great success during their education. 16 respondents or $12.69 \%$ of the total sample of respondents who have committed sexual or blood torts had very good success in school. The data for these categories will not be commented because the representation in the sample is less than 20.70 respondents or $55.5 \%$ of the total sample of respondents who committed sexual or blood torts had good success during their education. 42 respondents or $60 \%$ committed a sexual offense and 28 respondents or $40 \%$ committed a blood tort. These data show that the respondents who achieved good success in school demonstrate a higher probability to commit sexual misdemeanors. 9 respondents or $7.19 \%$ of the total sample who committed sexual or blood torts during their education showed only satisfactory success. These data will not be commented because the representation in the sample is less than 20.20 respondents or $15.78 \%$ of the total sample who committed sexual or blood torts have once repeated a year. 4 respondents or $20 \%$ committed a sexual offense and 16 or $80 \%$ committed a blood tort. These data show that the respondents who repeated a year once throughout their education have a higher probability to commit a blood tort. 5 respondents or $3.96 \%$ of the total sample who committed sexual or blood torts repeated twice during education. These data will not be commented because the representation in the sample is less than 20. Based on these data, we can conclude that the respondents who achieved good success in school demonstrate a greater probability to commit sexual misdemeanors. 
Those that repeated once during the educational process stand a greater chance to commit blood torts. The success during education is a relevant factor in committing sexual offenses.

\section{The impact of the occupation on the conduct of respondents who committed sexual or blood torts}

Regarding the impact of the occupation on the conduct of respondents who committed sexual or blood torts it is assumed that the two samples tested are significantly different when it comes to statistics. 74 respondents or $58.26 \%$ of the total sample who committed sexual or blood torts are without occupation. 35 respondents or $47.3 \%$ of the total sample committed a sexual offense and 39 or $52.7 \%$ committed a blood tort. These parameters show that the respondents with no occupation manifest an equal probability to commit sexual or blood torts. 13 respondents or $10.23 \%$ of the total sample who committed sexual or blood torts are workers by profession, 8 respondents or $6.25 \%$ are traders, 4 respondents or $3.14 \%$ are drivers, 5 respondents or $3.95 \%$ are clerks, 2 respondents or $1.57 \%$ are professors, 6 or $4.72 \%$ are farmers, 2 or $4.72 \%$ are herders. The data for this category will not be commented because their participation in the sample is less than 20. Based on this data set we can conclude that the respondents who are workers by profession demonstrate an equal probability to commit sexual or blood torts. Occupation is an irrelevant factor in the commission of sexual or blood torts.

\section{The impact of premarital sexual experience on the conduct of respondents who committed sexual or blood torts}

Regarding the impact of premarital sexual experience on the conduct of respondents who committed sexual or blood tort in this research it is assumed that the two samples tested are significantly different when it comes to statistics. 101 respondents or $79.52 \%$ of the total sample of respondents who committed sexual or blood torts had premarital sexual experience. 56 respondents or $55.4 \%$ of the sample committed a sexual tort and 45 or $44.46 \%$ committed a blood tort. These data indicate that respondents who had premarital sexual experience are more likely to commit sexual misdemeanor. 26 respondents or $20.47 \%$ of the total sample who committed sexual or blood torts did not have pre-marital sexual experiences. 8 respondents or $30.8 \%$ committed a sexual tort and 18 or $69.2 \%$ committed a blood tort. These data indicate that respondents who do not have pre-marital sexual experiences are more likely to commit blood torts. Based on this data set, we can conclude that the respondents who had pre-marital sexual experience demonstrate a higher probability to commit sexual misdemeanors. Premarital sexual experience is a relevant factor in the commission of sexual offenses.

10. The impact of recidivism (privious convictions) on the conduct of respondents who committed sexual or blood torts

Regarding the impact of recidivism on the conduct of respondents who committed sexual or blood torts in this research it is assumed that the two samples tested are each statistically significantly different. 51 respondents or $40.15 \%$ of the total sample of respondents who committed sexual or blood torts are recidivists. 33 respondents or $64.7 \%$ committed sexual torts, and 18 respondents or $35.3 \%$ committed blood torts. These data suggest that the respondents who were previously convicted are more likely to commit sexual misdemeanors. 76 respondents or $59.84 \%$ of the total sample of respondents who committed sexual or blood torts have previously not been convicted. 31 respondents or $40.8 \%$ committed sexual torts and 45 or $59.2 \%$ committed blood torts. Based on the previously mentioned data we can conclude that the recidivists (respondents who were previously convicted) demonstrate a higher probability to commit sexual misdemeanors. Recidivism (previous convictions) is a relevant factor in the commission of sexual offenses.

\section{CONCLUSION}

By nature, a human being is a complex form of constantly moving living matter. Its moving shapes humans as instinctive, emotional, and rational beings. These are fundamental elements which determine the specific existence of human beings. The combination of these elements also influences thinking, ways and extent to which instincts will be realized. Man is the result of social history and is a generic, practical being. Man can change nature and him/herself with his own effort. In line with this thinking, generic and individual human characteristics emerge and the way they are modified and shaped depends on particular historic conditions. 
Within such historic framework of human genesis, we aim to understand and explain sexual assault as criminal phenomenon throughout the entire history of human society. We maintain that sexual abuse as well as other crimes is the most serious form of alienation, above all in the spiritual domain of man's existence. In an attempt to solve piled up problems, man as a living, material, thinking and practical being behaves in line with determined criteria of his/ her own existence. This effort is visible in each individual in the intimate persistence to stay alive, continue the human kind, find ways for a happy life. In this struggle, one does not always manage to grow into an individual with authentic optimal integrative components that should find solutions to life's problems. This is why the individual sets irrational goals, opting for the evil (sexual assault) as a mode of existing. Sexual assault only temporarily and seemingly brings into order circumstances which hinder intrapsychic satisfaction and individual image of the actual state of affairs.

A particularly important element in the genesis of sexual crime is the distinct individuality of sexual offenders and personal characteristics which appear as subjective criminogenic influence. In this context, we must point out certain social factors from the social environment. Our research shows that sexual crime doers differ from murderers in oppositional traits, psychoticism scale and psychological type (introvert-extrovert). Education and occupation are irrelevant for sexual assaults. Successful education, premarital sexual experience, and recidivism are relevant factors for committing sexual assaults. These psychological and social characteristics in a specific social setting and situation usually prefer sexual assault. These are essential factors according to which respondents from experimental and control groups statistically differ significantly.

\section{REFERENCES}

Andertson,W. P. Kunle , J. T. and Rich. B.(1976): Sex offenders:The personality: Types Jurnal of Criminal Psychology, 35/3, pp. $671-676$

Ačimović, M. (1976). Pravci kriminalne psihologije, Beograd: Savremena administracija

Bandura, A. and Wolters, R. (1965). Adolescent aggression. New York: The Ronald press company, pp.134 - 147.

Berkowitz, L. (1962). Agression, New York: McGrow-Hill

Ellis, A. (1965). The Sex offender and his Treatement, Legal Criminal Psihology, New York: Halt Rinchard and Winston

Eysenk, J.H. Crime and personality, Rontledge Kegan Paul, ELT, Brodwey Hous, pp. 68 - 74, Center London, E.C.

From, E. (1976). Anatomija ljudske destruktivnosti, Zagreb: Naprijed

Fulgozi, A. (1987). Psihologija ličnosti, Zagreb: Školska knjiga, p.386

Hawels, K. and Wright, E. (1978). The sexual Attitudes of Aggressive Sexual Offenders The British Journal of Criminology, 2, pp. $170-175$

Kron, L. (1989). Problem psihičkih tumačenja i istraživanja ličnosti seksualnih prestupnika, Beograd: JPKKP, pp.137 - 150 Kreč, D. and Krečfild, R. (1980). Elementi psiohologije, Beograd: Savremena adminstracija, pp.171 - 188 